\title{
Competitiveness of Professional Education: Purposes, Tasks and Factors of Its Participation in the International Educational Services Market
}

\author{
Nina Andreyevna Ivanenko ${ }^{1}$, Irina Valentinovna Khairova ${ }^{2}$, Aigul Linarovna Fajzrakhmanova ${ }^{2}$, Tatiana \\ Viktorovna Khalilova ${ }^{3}$, Guzyal Mansurovna Kharisova ${ }^{4}$, Tatyana Borisovna Lisitzina ${ }^{5} \&$ Svetlana Fanusovna \\ Shaimukhametova ${ }^{6}$ \\ ${ }^{1}$ Technical College at Kazan National Research Technical University named after A. N. Tupolev, Russia \\ ${ }^{2}$ Kazan Federal University, Russia \\ ${ }^{3}$ Kazan National Research Technological University, Russia \\ ${ }^{4}$ Kazan State University of Architecture and Engineering, Russia \\ ${ }^{5}$ Gzhel State Art and Industry Institute, Russia \\ ${ }^{6}$ The Institute of Economics, Management and Law, Russia
}

Correspondence: Nina A. Ivanenko, Technical College at Kazan National Research Technical University named after A. N. Tupolev, Kazan, K.Marks Street, 10, Tatarstan, 420111, Russia. E-mail: nina.ivanienko@mail.ru

\author{
Received: September 30, 2014 Accepted: November 14, 2014 Online Published: December 2, 2014 \\ doi:10.5539/ass.v11n1p369 \\ URL: http://dx.doi.org/10.5539/ass.v11n1p369
}

\begin{abstract}
The article is directed at research of professional education competitiveness problem under the conditions of the international educational integration. The essence of competitiveness of professional education is revealed in it and such components as: competitiveness of specialty and higher educational institution, competitiveness of vocational training, competitiveness of educational services, competitiveness of a student, competitiveness of a graduate and competitiveness of an expert are also revealed here. The purposes and tasks are presented in the article, the features of competitiveness of professional education are revealed, and also factors of competitive participation of the Russian professional education at the international market of educational services are defined.
\end{abstract}

Keywords: competitiveness; professional education; international market of educational services; features, purposes, tasks, factors of competitiveness increase; criteria of competitiveness

\section{Introduction}

The modern situation at the domestic market of educational services is becoming more and more strained because of initiating of a two-level system of higher education; because of accession of Russia by the WTO which will strengthen competitive fight between domestic, western and eastern producers for the Russian markets (Baydenko, 2002); because of ranging of higher educational institutions and their graduates according to the competitiveness level; because of transition to the third generation of federal educational standards; because of Russian students' number reduction due to demographic recession of the population; because of acceleration of globalization processes, because of operated objects competitiveness increasing (Zayarnaya, 2006; Aydrus, 2009); because of integration in the world of social and economic structures; because of strategic branding, marketing, planning, management development; because of the technological way restoration which is characterized by innovative breaks on the basis of nano - bio - global digital information technologies, in a chain "education - science - production"; because of improvement of quality and accuracy of processes: marketing (on the basis of a benchmarking), informational, economic, administrative, production, ecological, social, etc. (Tregubova, Masalimova, \& Sakhieva, 2013); because of growth of corporate educational institutions (universities, centers, business schools, etc.) (Mukhametzyanova \& Shaydullina, 2011). All this generates a problem of searching new sources of higher educational institutions competitiveness increase. 


\section{Methodological Framework}

Problems of competitiveness of professional education under the conditions of consistent educational space were considered by us in the research. They have such components as: competitiveness of specialty and higher educational institution, competitiveness of vocational training, competitiveness of educational services, competitiveness of a student, competitiveness of a graduate, competitiveness of an expert.

Competitiveness - initially it is an economic category, used as the characteristic of goods (services); it was not used anywhere, except economy, for a long time. In recent years, due to universal commercialization, transition of all national economy of Russia to "market rails", we began to use this term for experts. It is quite clear that competitiveness of experts can be defined through concept of competitiveness of goods as at the labor market experts are "sellers" of professional knowledge, skills and they compete with each other for workplaces (Altunina, 2011; Buharov, 2011; Chernilevsky, 2002; Kim \& Lee, 2012).

Competitiveness of educational institution is an ability to be more attractive to consumers of the educational services (youth, parents and employers), suppliers and investors, using best external and internal opportunities, in comparison with competitors, keeping financial stability for increasing their "business cost" (Glukhov, 2004; Vertil, 2011). This rendering, in our opinion, reveals the essence of competitiveness concept most fully. Indicators of competitiveness of educational institution or specialty are: social status of a profession, specialties that include economic opportunities of representatives of this profession; objective estimates and subjective opinions about the concrete higher educational institution activity (location, material resources, traditions, potential, professionalism of teachers, the diploma rating, used educational technologies, etc.).

Competitiveness of professional training - professional opportunities which are given to young specialists upon termination of higher educational institution, and also such quality of professional education which will allow them to realize these opportunities (Hazova, 2011). It is defined by an orientation to formation of professional competence of experts and depends on the following indicators: range of opportunities at a choice of professional activity direction: existence of adjacent specialties and possibility of their development at a higher educational institution; opportunity to raise or change qualification independently; orientation to educational process at a higher educational institution to a multiple types specialists training (Teplov, 2001); quality of professional training that provides high level of personal and special competence of the expert. The competitiveness is also provided with an orientation to professional training towards the branch and regional interests, with rational structuring the content of education and using effective educational technologies.

Competitiveness of educational services presents their ability to keep the competitive advantages and to compete at the market of educational services being constantly improved for a long time. Indicators of competitiveness of educational services are the following: quality of training syllabus (structure and contents); quality of the teachers' staff (qualification, rank, scientific degree, preparation level); quality of methods of training and education (technique and technology of teaching); quality of resource ensuring process of service: material (lecture rooms and laboratories, equipment, expendable materials); informational and methodical (educational literature, grants, collections of tasks, models, exercise machines, etc.) ; quality of scientific researches; quality of the organization and realization of used technologies of providing educational services (form and content of educational processes, motivators); quality of control the process of providing educational services; quality process providing educational services result (compliance of students and graduates' knowledge level to requirements of the state educational standard of specialties); high satisfaction of consumers (pupils, employers, etc.) quality of educational services; high satisfaction of teachers and staff of educational institution with the work; high degree of society members education (Rosentsvaig, 2008).

Competitiveness of a student - an integrative indicator of compliance of his knowledge, skills to requirements of State standard and the generalized requirements of social and economic development of society. The last one can include: social competences (communicative qualities, tolerance, corporativity); professionally significant psycho-physiological traits which are indicative for this or that profession (sight, hearing, reaction and coordination of movements, memory development, state of health); professional and important personal qualities indicative for a profession in a whole (responsibility, organization, discipline etc.) (Mitina, 2002; Bakar, \& Hanafi, 2007). Indicators of competitiveness of a student: compliance of knowledge and skills to requirements of State standard and to the generalized requirements of social and economic development of society; formation of social competences (communicative qualities, tolerance, corporativity); formation of professionally significant psycho-physiological traits indicative for this or that profession (memory development, a state of health and so on); formation of professional and important personal qualities indicative for a profession in a whole (responsibility, organization, a discipline, etc.) (Gilmeeva, 1998). 
Competitiveness of a graduate is an integrative indicator of his or her readiness for future professional activity, including the competences that influence the employment, defined by requirements of the generalized or specific employer. They are: professional competences (knowledge, abilities and skills according to the employers' requirements); professionally significant and professionally important qualities as the employers require. Indicators of competitiveness of the graduate are: formation of professional competences; formation of professionally significant and professionally important qualities that the employers require; readiness of the graduates for professional activity; demands of the labor market for the graduates (Ivanenko, 2014).

Competitiveness of an expert in a general can be defined as the integrative characteristic providing him or her higher professional status, higher rating position at the corresponding branch labor market, steadily great demand for his or her services. It is defined by degree of compliance of personal qualities and professional knowledge, skills of the expert to objective professional activity requirements and social and economic conditions; it develops under the influence of some factors. Indicators of competitiveness of the expert: the personal trait of an expert that provides formation of his or her professional (special and personal) competence: characteristics of professional thinking and consciousness, professionally significant personal qualities necessary for realization various professional functions); knowledge quality, skills of social and professional communication, experience of professional activity, behavior and communication, duration of the graduates' becoming permanent at the job.

Therefore, competitiveness of professional education in the conditions of integrated educational space represents the property of professional education that characterizes a degree of its real and potential ability to satisfy most attractive educational services requirements, than competing systems of professional education have, and also reflecting a superiority over competitors in a number of defining indicators, such as financial and economic, marketing, material, personnel and socio-political, and also ability of higher educational institution to function without crises and adaptation to changing environmental conditions. The emphasis is stressed at such signs which reflect the content of the concept "competitiveness of higher educational institution" in this definition as: superiority over competitors in a number of defining indicators; higher educational institution functioning without crises; ability of timely adaptation of higher educational institution to changing environmental conditions

\section{Results}

It is possible to distinguish the following objectives of competitiveness increase of a higher educational institution of professional education as strategic ones: formation of higher educational institution image as a higher educational institution with the world name confirmed with the international certification of quality management system; ensuring integration of education, science and production, including a combination of higher educational institution processes of management of innovations and educational process; realization of advancing satisfaction of inquiries system as external consumers. They are students, the enterprises, partners and society in a whole. Internal consumers are the staff of higher educational institution. Providing system guarantees acquisition of knowledge, abilities, culture and complex preparation for self-realization in society; creation of conditions for effective corporate administration of quality management system while training specialists; providing internal quality assurances of educational services (Petrov \& Suhov, 2007).

The tasks of the above-named realization purposes are: integration of educational, scientific and practical activities in the perspective scientific and educational directions on the basis of knowledge economy development and preservation of higher educational institution traditions as a leader; deep fundamental and practical training of students as a major factor of experts' quality improvement and their competitiveness at a labor market; satisfaction of the current and perspective requirements for receiving higher education due to creating intellectual potential; high quality of educational and scientific processes ensuring; defining the degree of employers needs satisfaction for the purpose of their advancing and broad interaction with the interested organizations and the enterprises of any type of ownership while forming the syllabus.

Features of competitiveness of professional education are shown in the following:

1) competitiveness is strengthened with the number of competing higher educational institutions increase;

2) competitiveness is amplified while small higher educational institutions join larger ones that promotes their becoming the leading higher educational institutions;

3) competitiveness is amplified when demand for educational services grows slowly;

4) competitiveness is amplified when one or several higher educational institutions are not satisfied with their own activity;

5) competitiveness of higher educational institution is amplified while providing educational services in an innovative mode using modern information technologies and a "know-how"; 
6) the course of the competition is predictable when strategy, resources, organizational features, missions of higher educational institutions differ considerably and are open for the majority.

Rating of higher educational institutions acquires great popularity in the conditions of the competition. Now various models of rating of higher educational institutions are used. However a system factor of any rating, including a higher educational institution rating is its purpose which defines rating methodology, structure of criteria and indicators, procedure of collection of information and data processing. It should be mentioned that the same higher educational institution that have a different target focus in the ratings can take absolutely different positions.

The disadvantage of some domestic and foreign ratings of higher educational institutions is the reference to all higher educational institutions as to integrated group of objects though they are considerably individual. It is impossible to make a qualitative rating of the higher educational institutions realizing different missions, using integrated system of criteria, indicators and data processing methods.

The rating of methodology disadvantage is the requirement often based on "objective" according to researchers, on informational, exact and checked indicators. However such kind of systems as a higher educational institution have essential and complete results of activity which are not formed into separate groups of indicators because the system have the emergent properties. The rating system of rather big significance has to include subjective data on activity of the higher educational institutions, received on the basis of correctly made expert estimates.

As factors of competitive participation of the Russian professional education in the international market of educational services the following ones were allocated in the research:

- macrofactors (at the level of the state): strengthening of programs of the academic mobility and cooperation between educational institutions of professional education developed and developing countries; expansion of opportunities for import of foreign academic models; development of the international educational information resources, that is providing systematized information about educational institutions, training programs and courses, creation of electronic collections of educational and methodical literature that provide necessary information for foreign students; subjects of educational process readiness for cross-cultural interaction in the conditions of integration processes in education, etc.

- mesofactors (at the level of the region): change of a role of vocational and higher educational institutions in educational space of the region; strengthening of regionalization of vocational and higher education; the variety of educational institutions that allow students to choose educational institution according to their educational requirements; integration of research independent institutes and universities; having foreign students, researchers and teachers in; occurrence and competition aggravation between educational institutions, etc.;

- microfactors (at the level of educational institution): enrollment of students and teachers on a competitive basis; granting to students freedom of choice of training courses and subjects for scientific researches; moral and material incentive as students as professors; integration of research and educational activity of educational institution; the developed grant activity of the educational institution, allowing competing at the market of ideas, etc. (Shaidullina \& Ivanenko, 2012).

The following criteria of competitiveness of any higher educational institution in the majority of ratings are defined: quality of pre-university preparation; quality of educational programs content; quality of the professors staff; quality of scientific researches; quality of material resources; quality of educational technologies; quality of students' research activity; quality of international education; quality of programs postgraduate education issuing.

Quality of the professors' staff is the most powerful factor in the higher technical educational institutions according to a result of questioning (28\%).Then the close interaction with a labor market comes while forming the content of education (25\%). The third place of importance takes the use of innovative technologies of training, educational and methodical and material providing of educational process (19\%). However, the results of questioning revealed the following disadvantages: first, the quality of management at the higher educational institutions is insufficiently estimated (only $11 \%$ ); secondly actions for formation of the academic mobility of subjects of educational process $(9 \%)$ are not fully realized; thirdly, insufficient number of test programs for system at the highest technical educational institutions (3\%) is realized.

\section{Discussions}

Modern research potential, terminological approaches, the theoretical and empirical development concerning studying problems that provides competitiveness of professional education establishments, achievement of 
strategic competitive advantages. They are not only exhaustive, but, on the contrary, predetermine the necessity of scientific search activation.

The term "competition" was borrowed by pedagogical science from economy. J. Mil (1980), F.A. von Heik (2003), F. Knight (2001) give a big variety of treatments of the competition. So, J. Mil proved that the competition itself is the law which establishes regulations. F.A. von Heik considered that "the competition leads to the best use of knowledge and abilities of people and stimulates rationality". F. Knight claims that "the competition is a situation in which there is a lot of competing units and they are independent".

The concept "competition" is closely connected with the concept "competitiveness". As well as the competition, the concept "competitiveness" - initially economic category, used at the characteristic of goods or services. The concept "competitiveness" was included strongly in psychology and pedagogical science and began to be studied in connection with consideration of professional activity of a person. Questions of competitiveness are investigated by V. I. Andreyev (1992), A. G. Shmelev (1997), T. V. Matveeva, N. V. Mashkova, E. V. Patrakov, O. V. Obukhov (2014), N. Avralev and I. Efimova (2014).

Stating variety and diversity of approaches to reveal different sides of competitiveness, it is necessary to emphasize that theoretical and methodological providing of the research about functioning of the market of higher education demand further development and specification in economy system. Moreover almost demanded studying of problems of providing competitiveness of establishments of professional education on the basis of the modern means of the marketing which haven't received so far the relevant decision is necessary.

However insufficient level of system study of theoretical and methodological and applied aspects of providing own competitiveness by the higher educational institutions, perspective development of strategic competitive advantages determined the general plan and the purpose of this article.

\section{Conclusions}

Thus we have revealed the essence of competitiveness of professional education in the conditions of the integrated educational space in this article. It presents the property of the professional education, being characterized ability of its functioning in non-critical mode, timely adaptation to changing conditions and a superiority over competing systems of professional education;

Macrofactors (at the level of the state), mesofactors (at the level of the region) and microfactors (at the level of educational institution) competitive participation of the Russian professional education in the international market of educational services are revealed.

The complex system of criteria and the indicators is defined on the basis of the analysis of rating models. It allows carrying out an independent assessment of competitiveness of higher educational institutions: quality of pre-university preparation; quality of syllabus content; quality of professors' staff; quality of scientific researches; quality of material resources; quality of educational technologies; quality of students' activity research; quality of international education; quality of issuing postgraduate educational programs.

The undertaken research showed that the pedagogical perspective is not settled by available scientific data. It will be considered: in further studying of pedagogical regularities of space modeling development of the university graduates competitiveness; in studying of individualization work problem with students on formation and development of their competitiveness at a labor market, in scientific development of universal pedagogical work model with the staff, creation of scientifically reasonable syllabuses and methodical documentation.

\section{References}

Altunina, V. V. (2011). Training of competitive specialists. Professional Education, 7, 34-35.

Andreev, V. I. (1992). Self-development of creative competitive personality of the manager (p. 207). Kazan. SCAM Press.

Avralev, N., \& Efimova, I. (2014). Global university rankings as indicators of the implementation of the integration process and competitive tool in the context of globalization of higher education. Life Science Journal, 11(10), 648-652.

Aydrus, I. A. (2009). Russia's position on the world market of educational services (Analytical Review). Alma mater, 2, 10-16.

Bakar, A. R., \& Hanafi, I. (2007). Assessing employability skills of technical-vocational students in Malaysia. $J$. Soc. Sci., 3, 202-207

Baydenko, V. I., \& Van Zantvort, J. (2002). Modernization of vocational education: Modern step (p. 674). 
Moscow: Research Center of the quality of training Press.

Buharov, D. V. (2011). Communicative competence in the management of the head of the image of the school as a basis for the competitiveness of the educational institution. Man and Education, 2, 135-138.

Chernilevsky, D. V. (2002). Didactic Technology in Higher Education: Textbook (p. 112). Manual for schools. Moscow. UNITY-DANA Press.

Gilmeeva, R. H. (1998). Professionalism of teachers in the sociological dimension. Sociological studies, 11, 73-80.

Gluhov, S. V. (2004). Main characteristics of competitiveness of educational institutions. Innovative technologies in teaching and in the workplace, 2, 177-178.

Hayek, F. A. (2001). Individualism and Economic (p. 254). Moscow. Start Foundation.

Hazova, S. A. (2011). Development of the Competitiveness of specialists in physical culture and sports in the process of training (p. 370). Maikop. Adyghe State University.

Ivanenko, N. A. (2014). Pedagogical conditions of competitiveness in terms of college diversification of the Russian system of vocational training. Educational innovations, 6, 27-36.

Kim, Y. D., Yoon, S., \& Lee, K. S. (2012). International competitiveness of Korea service industry. Am. J. Applied Sci., 9, 343-349.

Knight, F. H. (2003). Risk, Uncertainty and Profit (p. 163). Moscow.

Matveeva, T. V., Mashkova, N. V., Patrakov, E. V., \& Obukhov, O. V. (2014). Ensuring competitiveness in the system of additional professional education. Life Science Journal, 11(8s), 426-429.

Mill, J. (1980). Principles of Political Economy (p. 140). Moscow: Progress Press.

Mitina, L. M. (2002). Developmental Psychology competitiveness personality (p. 112). Moscow. Voronezh Moscow Psychological and Social Institute, MODEK.

Mukhametzyanova, G. V., \& Shaidullina, A. R. (2011). Regional Integration Processes in the Vocational Education System (1st ed., p. 232). Idel Press.

Petrov, A., \& Suhov, S. (2007). Strategic management competitiveness of the university. Higher Education in Russia, 2, 9-15.

Rosenzweig, A., \& Smirnov, Yu. (2008). On innovation in the education system. Higher Education in Russia, 8 , 88-92.

Shaidullina, A. R., \& Ivanenko, N. A. (2012). Mechanisms for the preparation and selection of future competitive technical specialists. Professional education in Russia and abroad, 3(7).

Shmelev, A. G. (1997). Productive competition. Experience in designing a unifying concept (p. 55). Moscow. Masters Press.

Teplov, E. P. (2001). On the problem of the working model of the manager and the content of the educational program in the direction of 521500 (Bachelor of Management, with our focus on the field of sport) (p. 67). St. Petersburg. Balt-Nord Press.

Tregubova, T. M., Masalimova, A. R., \& Sakhieva, R. G. (2013). Competency model competitive specialist technical and humanitarian profile for a diversified system of additional vocational education (p. 62). Kazan. RAO Press.

Vertil, V. V. (2011). Formation of organizational-economic mechanism for the development of competitive institutions ACT. Vocational Education, 7, 6-12.

Zayarnaya, I. A. (2006). Motivational approach to the management of the educational institution. In the Proceedings of the IV International scientific and practical conference "Socio-economic problems of the development of enterprises and regions" (pp. $234-236$ ).

\section{Copyrights}

Copyright for this article is retained by the author(s), with first publication rights granted to the journal.

This is an open-access article distributed under the terms and conditions of the Creative Commons Attribution license (http://creativecommons.org/licenses/by/3.0/). 